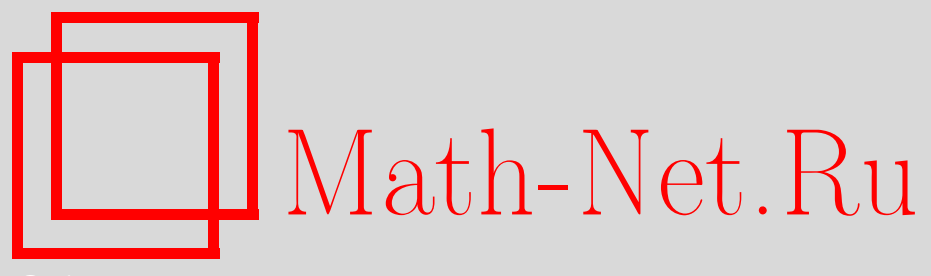

Конкурсы фонда Д. Зимина "Династия" и Пьера Делиня для молодых математиков, УМH, 2007, том 62, выпуск 1, 219-222

DOI: https://doi.org/10.4213/rm6222

Использование Общероссийского математического портала Math-Net.Ru подразумевает, что вы прочитали и согласны с пользовательским соглашением http://www . mathnet.ru/rus/agreement

Параметры загрузки:

IP : 52.23 .180 .231

26 апреля 2023 г., 14:42:30

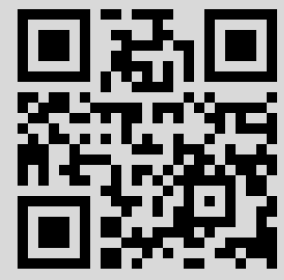




\title{
Конкурсы фонда Д. Зимина “Династия" и Пьера Делиня для молодых математиков
}

\author{
Конкурс фонда Д. Зимина "Династия" \\ для молодых математиков (правила)
}

\section{1. Преамбула}

Конкурс фонда Д. Зимина "Династия" это конкурс молодых математиков России, победителям которого назначается трехлетняя стипендия. Цель конкурса - помочь молодым математикам заниматься научной работой у себя на Родине.

Фонд некоммерческих программ "Династия" (http://www.dynastyfdn.ru) - благотворительная организация, основанная в 2001 г. Д. Б. Зиминым - почетным президентом компании "Вымпелком". Фонд ставит своей задачей развитие и популяризацию российской фундаментальной науки. В числе действующих программ фонда - программа поддержки студентов, аспирантов и молодых ученых, программа поддержки преподавателей физики и математики, проект "Элементы” (программа популяризации науки) и многое другое. Фонд организует конференции (в том числе конференцию "Молодые ученые России"), летние научные школы, публичные лекции. Так, недавно в Москве с успехом прошли лекции по физике и математике, организованные фондом при поддержке Международного центра фундаментальной физики в Москве. С лекциями выступили Нобелевский лауреат по физике 2004 г. Дэвид Гросс и академик В. И. Арнольд.

\section{2. Проведение конкурса}

В конкурсе может участвовать любой житель России не старше 35 лет (т.е. человек, которому в год подачи заявки на участие в конкурсе исполняется не более 35 лет), имеющий степень кандидата или доктора физико-математических наук.

Участник конкурса представляет жюри исследовательский проект, рассчитанный на три года, а также другие документы, перечисленные ниже в разделе "Подача заявки". Жюри конкурса выбирает нескольких рецензентов (из числа предложенных участником конкурса и/или по своему усмотрению) и отправляет им проект на отзыв (при этом жюри передает рецензентам весь пакет документов, представленных на конкурс). Затем жюри обсуждает поданные заявки и отзывы рецензентов и выбирает победителей конкурса. Крайний срок подачи заявок на следующий год - 15 октября текущего года.

\section{3. Победители конкурса}

Каждый победитель конкурса получает диплом фонда Д. Зимина “Династия" и трехгодичную стипендию в размере 15000 рублей в месяц. Стипендия будет начисляться ежеквартально, начиная с января того года, на который она присуждена. 
(То есть стипендии, присужденные в декабре 2006 г., начинают начисляться с января 2007 г., и т. д.) Выплата будет происходить в первую неделю следующего квартала (например, стипендия за январь-март 2007 г. будет выплачена до 7 апреля 2007 г.). Грантодержатель информирует Фонд в случае отъезда из России на срок более двух месяцев в течение текущего года, при этом выплата стипендии приостанавливается на соответствующий срок. При отъезде на срок свыше четырех месяцев выплата стипендии прекращается.

В конце каждого года стипендиат должен представлять жюри краткий отчет о достижениях прошедшего года и о планах на будущий. В нормальной ситуации жюри утверждает отчет и принимает решение о продолжении выплаты стипендии. По окончании срока выплаты стипендиат должен представить итоговый отчет.

Во всех научных работах, выполненных стипендиатом в период получения стипендии, должно содержаться указание на то, что они были осуществлены при частичной финансовой поддержке фонда Д. Зимина "Династия".

\section{4. Жюри}

Жюри конкурса фонда Д. Зимина "Династия" выбрано специально для этого конкурса и не зависит от каких-либо университетов или других организаций.

В состав жюри входят два сопредседателя, два заместителя председателя, два научных секретаря и члены жюри - эксперты в различных областях математики. Жюри может быть расширено по единогласному решению членов жюри, при условии что по крайней мере четверть членов жюри присутствует при принятии решения. Жюри нанимает специального сотрудника для решения технических вопросов.

Состав жюри. П. Делинь (сопредседатель), В.А. Васильев (сопредседатель), М. С. Агранович, В.К. Белошапка, А.В. Булинский, Ю. М. Бурман (научный секретарь), В.М. Бухштабер, А. М. Вершик, Э.Б. Винберг, А.Л. Городенцев, С. М. Гусейн-Заде, М.И. Зеликин, Ю. С. Ильяшенко (заместитель председателя), В. Ю. Калошин, В.В. Козлов, С.К. Ландо, С. В. Матвеев, С. М. Натанзон, Л. А. Пастур, А.А. Разборов, А.Г. Сергеев, И.А. Тайманов, Д. В. Трещев, Б. Л. Фейгин (заместитель председателя), А.Я. Хелемский, А.Г. Хованский, М. А. Цфасман, А. Х. Шень (научный секретарь), Л. П. Шильников, А. Н. Ширяев.

\section{5. Подача заявки}

Сроки. Все необходимые документы должны быть в распоряжении жюри до 15 октября текущего года. Конкурс проводится, как правило, в декабре; победители конкурса получают стипендию, начиная с января следующего года.

\section{Список необходимых документов.}

1) Краткое изложение заявки (summary) - 1 страница.

2) План исследования (Research statement) - не более 5 страниц + библиография любого объема.

3) Краткая научная автобиография (Curriculum vitae) - 1 страница, и к ней отдельно приложить:

4) Список публикаций.

5) Список из трех потенциальных рецензентов проекта.

Предполагается, что в их число войдут математики, знакомые с участником конкурса лично или по работам и готовые дать отзыв о проекте.

6) Рекомендация научного руководителя (не обязательно). 
7) Оттиски научных работ, которые участник конкурса считает важными для оценки его заявки.

В список публикаций (п. 4)) можно, разумеется, включать и другие работы.

8) Список других научных грантов участника конкурса.

Адрес. Все необходимые документы следует прислать

- по электронному адресу dfc@mccme.ru,

а также

- по почтовому адресу: 119002, Москва, Б. Власьевский пер., 11, конкурс фонда Д. Зимина "Династия".

$$
* * *
$$

\section{Отчет о Конкурсе Пьера Делиня за 2005 г.}

30 декабря 2005 г. в Москве произошло награждение победителей Первого Конкурса Пьера Делиня для молодых математиков. Жюри конкурса выделило группу из 12 человек, каждый из которых был сочтен лидером в своей области. На конкурс было представлено 43 заявки, многие из них - очень высокого уровня. К сожалению, по условиям конкурса можно было присудить только 5 премий. Жюри заседало два дня в Независимом Московском Университете, и на второй день назвало имена победителей. Ими стали: П. Колесников (Новосибирск), А. Кузнецов (Москва), М. Ровинский (Москва), А. Скопенков (Москва), С. Шадрин (Москва).

Конкурс организован Пьером Делинем после получения им премии Э. Бальзана в 2004 г. По условиям Фонда Бальзана, половина суммы от врученной премии должна быть потрачена на поддержку молодых исследователей. На торжественной церемонии в Риме Пьер Делинь объявил о решении поддержать "борющихся русских математиков".

В интервью, данном polit.ru в январе 2006 г., Делинь сказал: "В России я видел прямой, кратчайший способ помочь людям, которые борются за выживание во всех смыслах. Им приходится заниматься наукой в неординарных условиях - и возникает опасность того, что сильная математическая русская школа может постепенно исчезнуть. Удручает то, что правительство им не помогает, хотя необходимость этого очевидна. Но не надо дожидаться момента, когда этот источник иссякнет и его нужно будет долго восстанавливать. Так было в случае с Германией. До наступления нацистских времен она была самым сильным математическим местом в мире, и понадобилось пятьдесят лет, чтобы там вновь появилось много замечательных математиков. $\langle\ldots\rangle$

Я считаю опыт первого года конкурса очень удачным. Нам представили много прекрасных проектов, и было действительно тяжело выбрать только пять человек из сорока трех. Я думаю, что по крайней мере десять человек достойны того, чтобы их отметили. После стольких тяжелых лет в России обнаружилось достаточно замечательных молодых людей. Это говорит о том, что уровень образования все еще очень хорош, включая среднее и специальное школьное образование. Очевидно, что система математических кружков прекрасно работает. И надо просто, чтобы люди могли получать достойную зарплату и не уезжать из России, чтобы поддерживать тот уровень, который достигнут. $\langle\ldots\rangle$

Математика - это прежде всего искусство. Меня привлекает красота, а не использование математики. И я думаю, что в науке красота очень важна. Мы же не спрашиваем художника, почему он не делает что-то более употребимое и легко используемое. Он делает то, что хочет, и все. Опасно искать в фундаментальной 
науке только пользу. Дело в том, что в математике по-настоящему важные вещи мы не можем планировать, как это бывало в компьютерных технологиях или квантовой механике. Очень часто то, что в конечном итоге хорошо используется, не было придумано для практического использования. Это не был поиск только приложений. Может быть то, что ищется и доказывается сегодня, найдет практическое применение через несколько лет. Но мы этого не знаем наверняка. Я думаю, поиск должен быть свободным, потому что не все может быть немедленно применимо. И очень важно защищать возможность людей делать что-то бескорыстное, без практического использования".

\section{$* * *$ \\ Отчет о Конкурсах Пьера Делиня и Фонда Д. Зимина “Династия" для молодых математиков}

28 декабря 2006 г. Жюри назвало имена победителей первого конкурса Фонда Д. Зимина "Династия" и второго конкурса Пьера Делиня. Ими стали: Э. Гирш (Санкт-Петербург), Д. Пионтковский (Москва) и А. Райгородский (Москва) по конкурсу Фонда Д. Зимина “Династия”; Д. Борисов (Уфа), М. Бондарко (Санкт-Петербург), С. Локтев (Москва), Т. Панов (Москва), Л. Рыбников (ИТЭФ, Москва) по конкурсу Пьера Делиня.

Правила двух конкурсов отличаются в одном пункте: победителям конкурса Пьера Делиня разрешается более долгий срок пребывания за рубежом.

Оба конкурса проводились совместно. На конкурсы было подано 72 заявки, почти все - очень высокого уровня. По переписке был сформулирован "короткий список" из 32 заявок. Он и обсуждался на заседании Жюри с 26 по 28 декабря. По каждой заявке было назначено несколько рецензентов и ответственный член Жюри, который докладывал на заседании содержание заявки и рецензий. После неторопливого и всестороннего обсуждения было проведено несколько туров голосования.

Каждый тур выделял несомненных победителей и отсекал несколько заявок, не прошедших в следующий тур. Оставшийся более короткий список снова обсуждался. Последнее голосование проходило по двум претендентам.

Первый тур голосования выделил 18 финалистов, каждый из которых, по мнению Жюри, был достоин присуждения стипендии. Но, к сожалению, стипендий было только 8. Жюри надеется, что в следующих конкурсах все (или почти все) финалисты 2006 г. получат стипендию одного из двух конкурсов. Конкурс Пьера Делиня будет проводиться в 2007-2008 гг.; конкурс Фонда Д. Зимина “Династия" в 2007-2010 гг. с возможным продолжением.

Мы поздравляем победителей и ожидаем в будущем новых замечательных заявок. 